\title{
CHURCH CORPORATIONS AND THE CONFLICT OF LAWS IN ANTEBELLUM AMERICA
}

\author{
KELLEN FUNK
}

$\mathrm{PhD}$ Candidate, Princeton University

\begin{abstract}
Scholars frequently describe American religious disestablishment using commercial analogies, reckoning that states "privatized" religion or subjected churches to "free-market competition" by making them more like commercial businesses, yet this article demonstrates in part how churches pioneered many of the corporate devices that came to define American enterprise after the Civil War. Such descriptions are thus anachronistic. Antebellum jurists were not concerned about the similarity of churches to businesses, but rather their similarity to states, and the republican fear that churches could be rival sovereign states at first structured the law of disestablishment and incorporation. In most states, churches gained rights of general incorporation but faced significant limitations on their corporate governance and property holdings. In Dartmouth College, the Marshall Court reimagined religious societies as private owners who, instead of governing as rival sovereignties, administered property in trust under their charters. But with the vague charters of general incorporation, state judges were left without a definite source of law to adjudicate church disputes. This article argues that courts thus allowed trust law to function as a conflict of laws analysis: Judges treated religious doctrine as a foreign legal system with rules that could be ascertained and accorded respect in American courts. Such a move created a positive, corporate right of religious liberty that becomes obscured if one conceives of religious freedom only as an individual right to be asserted against the state.
\end{abstract}

KEYWORDS: corporations, property, church and state, conflict of laws, disestablishment

Early in March 1765 , a group of more than a hundred German immigrants gathered around a vacant lot on Nassau Street in the small but rapidly growing city of New York. At the center of the gathering stood the Reverend Johann Michael Kern, a recent arrival from Heidelberg in the Lower Palatinate. Seven years earlier many among the group had founded the first German Reformed church in the colony of New York. Early on, the congregation had struggled to install a reliable minister, so finally in 1763 the elders applied for help directly from the consistory of Heidelberg-a well-known bastion of the German Reformed faith whose name was attached to one of the most eloquent catechisms produced in the Reformation world. The consistory selected Kern and dispatched him to fill the minister's post in New York City. ${ }^{\mathrm{I}}$

I Records of the German Reformed Church are held at the New-York Historical Society (primarily covering 1758 I846) and the Reformed Church in America archives in New Brunswick, New Jersey (primarily I846-I968). Records of the German Reformed Church of New York City, Membership, I759-I767, New-York Historical 
The timing of Kern's arrival was fortuitous. During the early winter of 1764 , a heavy snowfall had permanently damaged the church's meeting place in an old theater. Through a mix of sizable contributions as well as sizable debts, the congregation was now ready to build its first church edifice. On March 8, the German Reformed congregants gathered with several honored guests to celebrate. Upon setting the cornerstone, Reverend Kern dutifully delivered his pastoral remarks. Echoing the words of the patriarch Jacob, he proclaimed, "This stone which I erect shall be a house of God." Each member of the church's consistory then laid his own foundation stone, each time repeating the purpose, "for a German Reformed Church." Kern's closing remarks elaborated on his opening theme. "In the house to be built on this foundation stone," he assured his audience, "shall be taught the word of God, pure and unadulterated, according to the reformed doctrines of Heidelburgh and Switzerland" - the "and Switzerland" paying homage both to the heartland of reformed theology and to three noteworthy visitors from the canton of Zurich attending the ceremony. ${ }^{2}$

Kern's promise to teach the scriptures "according to the reformed doctrines of Heidelburgh" was, at its essence, a theological statement, an ecclesiastical assurance from a new minister to his expectant congregation. What neither Kern nor anyone else in the congregation could have expected was that nearly a century later those same words would become a legal statement, a binding charitable trust that a New York court would use in order to enforce Calvinist orthodoxy in the German Reformed church.

That such a turn could develop is a striking irony. At the time the German Reformed were constructing their building, the state took no cognizance of the religious society (the new building and land were owned by individual members). Only the state-established Anglican Church (as well as a few Dutch holdovers from the New Amsterdam era) enjoyed a corporate charter that created a legal personality to hold property and appear in New York's courts. By the I840s, all the American states had committed themselves to protecting freedom of conscience and withdrawing the state from ecclesiastical affairs through disestablishment. Yet it was then that courts in almost every state deeply examined the theological stance of various churches and on occasion transferred ownership of a church's "temporalities" - the buildings, revenues, and corporate identity - to a faithful minority of the congregation.

This article explores these puzzling cases that seem to have invaded the very heart of religious belief in American churches more than fifty years after many Americans had celebrated the achievement of religious liberty. Most American states disestablished their official churches by making corporate charters available to all "religious societies," an early form of what become known as general incorporation. But the proliferation of church charters posed a dilemma for judges who sought to respect both religious freedom and state sovereignty at the same time. After the Supreme Court reasoned that religious societies were merely distributors of private property and did not exercise governance as rival sovereignties, state courts increasingly protected religious freedom in an unexpected way- not as an individual right asserted against the state, but as a religious society's institutional right to see its alternative legal order respected in American courts. The law of charitable trusts critically facilitated this process, as judges turned to the law of trusts to fill out the

Society Museum \& Library, New-York Historical Society; In the Court for the Trial of Impeachments: Miller v. Gable, New-York Historical Society Museum \& Library, Yı 845, New-York Historical Society. Where no archive for litigation records or legal treatises is specified in this article, sources are available digitally in Google Books or the Gale Group's Making of Modern Law.

2 Facts recited in Gable v. Miller, Io Paige Ch. 620, 627 (N.Y. Chan. I844). 
details of vague church charters. In such cases the law of trusts ultimately functioned to transform theological systems into bodies of law that judges could then enforce.

\section{THE CONCEPT OF THE CORPORATION IN THE ERA OF AMERICAN DISESTABLISHMENT}

Scholars have become accustomed to thinking about American disestablishment through the use of commercial analogies. As the historian Nathan Hatch wrote in his seminal work on the Christianization of the early republic, disestablishment created an arena of "free-market pluralism" in American religion, and more recent scholars have spoken of disestablishment as a sudden "privatization of the church." ${ }_{3}$ In the conventional narrative, churches were thrust out of their privileged state positions into a private sphere of entrepreneurial competition, where the best populist innovators won the greatest followings. Churches thus operated like private businesses, newly freed from state regulation and enabled to compete in the marketplace of ideas. ${ }^{4}$

Talking about churches becoming like private businesses is to speak anachronistically, however. As this article illustrates in part, defining features of private business corporations in nineteenthcentury America often originated in church corporations. Disestablishment did not make churches like private businesses; rather it was only well after disestablishment that private business corporations became more like early religious societies. By the end of the nineteenth century, business enterprises could incorporate without having to seek the special permission of the legislature (general incorporation); they could conduct their affairs according to private discretion, knowing courts would defer to the decisions of directors (business judgment rule); and they benefited from a legal assumption that the very existence of these corporations served the public good by making entrepreneurial opportunities more readily available to all. Yet all of these precedents were set by church corporations, sometimes many decades earlier.

Further, in perpetuating a disestablishment-as-privatization narrative, twentieth-century historians gave too much weight to the preoccupations of their time and failed to understand the mindset of nineteenth-century jurists who surveyed their own world of corporate law and constitutionalism. As private business corporations have once again captured the attention of the American public, historians have unsurprisingly paid increasing attention to the development of these entities. Antebellum Americans had nearly the opposite focus, however. Churches dominated their vision, both conceptually and on the ground. As Pauline Maier sought to remind students of the corporate form, churches accounted for a vast proportion of early American corporations in the years that followed the Revolution. ${ }^{5}$ When the influential New York jurist James Kent systematized the law of corporations, he divided corporations into sole-an empty category consisting only of the old Anglican Church-and aggregate, the latter further subdivided into ecclesiastical and lay (see

3 Nathan O. Hatch, The Democratization of American Christianity (New Haven: Yale University Press, I99I), 2I 2; Kelly Olds, "Privatizing the Church: Disestablishment in Connecticut and Massachusetts," Journal of Political Economy I02, no. 2 (1994): 277-97, at 277.

4 Milton Powell, ed., The Voluntary Church: American Religious Life, 1740-1865, Seen through the Eyes of European Visitors (New York: Macmillan, 1967); Roger Finke and Rodney Stark, The Churching of America, 1776-2005: Winners and Losers in Our Religious Economy, 2nd ed. (New Brunswick: Rutgers University Press, 2005); Mark McGarvie, One Nation under Law: America's Early National Struggles to Separate Church and State (DeKalb: Northern Illinois University Press, 2004).

5 Pauline Maier, "The Revolutionary Origins of the American Corporation," William and Mary Quarterly, "Law and Society in Early America," special issues, 50, no. I (I993): 5I-84, at 5I-53. 
figure I). ${ }^{6}$ To Kent and the many American jurists following him, corporate law consisted quite literally of (I) churches and (2) the rest of the world, and only at the margins of that other world did one conceptually arrive at the subset of the private civil (business) corporation. In antebellum treatises, the paradigm corporation was a church, and the law reports reflected this preoccupation. As ubiquitous as corporate railroad litigation would become in postbellum case law, church litigation was equally pervasive in the antebellum period, and from this litigation one can learn much about the shape of American disestablishment.

\section{DISESTABLISHMENT BY GENERAL INCORPORATION}

The Anglo-American legal tradition had conceived of churches as corporations for centuries-but only certain churches. At first, only the Church of England and, over time, those churches that secured a special charter from the legislature gained the benefits of incorporation: a perpetual legal existence that could hold and transfer property and defend its rights in state courts. ${ }^{7}$ As it would in many other areas of law, New York set an influential legal example: it disestablished its official churches by making incorporation generally available to all religious societies.

Church establishments in the state reflected New York's heritage as both a Dutch and English colony. Across the eighteenth century, New York parishes were taxed to support the Anglican Church. ${ }^{8}$ Dutch Reformed congregations, however, enjoyed exemption from this tax and retained their corporate charters granted by New Amsterdam before I664, thus creating something of a dual-establishment for the colony. ${ }^{9}$ Dissenting denominations-such as the German Reformed Church-were tolerated but still expected to contribute to the support of the Anglican Church. No corporate charters were granted to dissenters. ${ }^{\text {I }}$

The process of disestablishment began with New York's revolutionary Constitution of I777, which followed other colonies in guaranteeing "the free exercise and enjoyment of religious profession and worship, without discrimination or preference" in order to "guard against that spiritual oppression and intolerance wherewith the bigotry and ambition of weak and wicked priests and princes have scourged mankind." Ir Although the Anglican (now Episcopal) Church lost its tax revenues, it retained its corporate charter and its impressive land holdings acquired during the era of establishment. The Dutch Reformed churches likewise retained their charters of incorporation, and in both cases, the New York revolutionary legislature passed legislation reaffirming the corporate charters of those assemblies that had been incorporated under English rule. ${ }^{\mathrm{I}}{ }^{2}$ It was on this

6 Diagram adapted from Hendrik Hartog, Public Property and Private Power: The Corporation of the City of New York in American Law, I730-I870 (Ithaca: Cornell University Press, I983), I97 (citing James Kent, Commentaries on American Law, 4 vols. (New York, I826-1830), 2:222).

7 Kent, Commentaries on American Law, 219-29.

8 See Michael W. McConnell, "Establishment and Disestablishment at the Founding, Part I: Establishment of Religion,” William and Mary Law Review 44, no. 5 (2003): 2105-208, at 2I34-35.

9 See ibid., 2I 29-30.

Io See Sanford H. Cobb, The Rise of Religious Liberty in America: A History (New York: Macmillan I902), 338-43. As late as $\mathbf{1 7 7 5}$, a Presbyterian church's request for incorporation was flatly denied by New York's legislative assembly. See McConnell, "Disestablishment at the Founding," 2 I 34.

I I N.Y. Const. of 1777 , art. XXXVIII.

I2 See Douglas G. Smith, “The Establishment Clause: Corollary of Eighteenth-Century Corporate Law?” Northwestern University Law Review 98, no. I (2003): 239-302, at 268-69ni I8. 


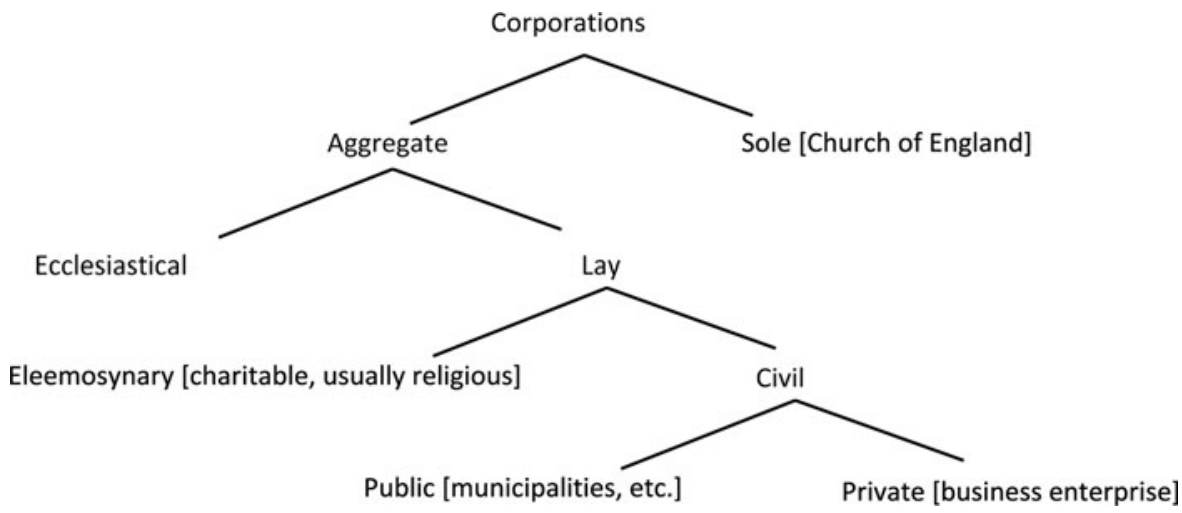

Figure I. The Universe of Corporations in Early American Law

occasion of rechartering that the New York Assembly decided to pursue disestablishment by making incorporation available for all religious societies.

The result of the legislature's reform was a ${ }^{7} 784$ "Act to enable all the religious Denominations in this State to appoint Trustees, who shall be a Body Corporate for the Purpose of taking Care of the Temporalities of their respective Congregations." ${ }_{33}$ The preamble hearkened back to the I777 constitution's guarantee of religious freedom "without preference" and commented at length on the inequalities of New York's unincorporated churches, which faced the uncertainty about who ultimately owned church properties and whether eventual heirs might someday dispossess the churches. The section read as follows:

$[\mathrm{M}]$ any of the churches ... have been put to great difficulties to support the public worship of God, by reason of the illiberal and partial distributions of charters of incorporation to religious societies, whereby many charitable and well disposed persons have been prevented from contributing to the support of religion, for want of proper persons authorized by law to take charge of their pious donations, and many estates purchased and given for the support of religious societies, now vest in private hands, to the great insecurity of the society. ${ }^{14}$

The Act then laid out the procedures by which any "church, congregation, or religious society" could gain incorporation. No longer would a congregation have to seek a special charter from the legislature. Rather, all male members of a religious society who were of age might elect trustees numbering between three and nine. Upon registration with the courts - not the legislature - the trustees would become a body corporate capable of holding property, existing perpetually, and suing in court. ${ }^{\mathrm{I}} 5$ The Act even specified the membership qualifications for voting: attendance for one year and monetary contributions "according to the usages and customs" of the particular assembly. ${ }^{\mathrm{I}} 6$

Although incorporation was not explicitly reserved for Christian assemblies, the language of the Act continually employed the jargon of Protestant Christianity: "denominations," "ministers," "elders," "deacons," "congregation." Significantly, the Act concluded by promising

I3 I784 N.Y. Laws 6I3-I8.

I4 Ibid., 6I3.

I 5 Ibid., 6I3-I4.

I6 Ibid., 6I7. 
[t]hat nothing herein contained, shall ... affect the rights of conscience or private judgment, or in the least to alter or change the religious constitutions or government of either of the said churches, congregations or societies, so far as respects, or in any wise concerns the doctrine, discipline or worship thereof. ${ }^{17}$

The legislature thus assumed that churches could be bifurcated: A congregation would be free to choose its polity and arrange its spiritual and doctrinal authority however it liked, and the state would stay out of these decisions. But the physical assets of the church were to be controlled by trustees who might not necessarily have spiritual qualifications to hold religious office. A religious society would have a business side and a spiritual side, and, at least in legislative theory, the former might never need to interfere with the latter.

In succeeding decades, the New York legislature occasionally reaffirmed the $\mathrm{I}_{7} 84$ Act while clarifying provisions for the formerly established churches. An editor of the I 8 I 3 reenactment noted of the original Act that "[i]ts beneficial effects were soon discovered, and the system, with but few alterations has continued down to the present time." ${ }_{18}^{8}$ One observer remarked that by the Civil War "most of the churches or societies" of various denominations in New York had incorporated under the Act. Many, like the German Reformed Church, incorporated almost immediately in the spring of $1784 .{ }^{19}$

New York's 1784 Act proved highly popular. Legislation copying the Act quickly appeared in New Jersey and Delaware, and with the exception of Virginia and a couple New England states, the major principles of the system were eventually adopted in every American state during the antebellum era. ${ }^{20}$ Some states, such as South Carolina, restricted incorporation only to Protestant Christian societies, while several other states allowed property to vest in a board of trustees without technically calling the result a "corporation." ${ }^{21}$ In litigation, however, such distinctions ceased to make a difference. In case after case, unincorporated churches-which either found themselves in jurisdictions that did not statutorily authorize incorporation or which had simply failed to avail themselves of such statutes-were transformed into corporations by the courts as a necessary requirement of equity. As a Vermont court reasoned, to require a charter for church incorporation "would be in effect to decide that our religious liberties were dependent on the will of the legislature, and not guaranteed by the constitution." Given the American commitment to religious freedom and the form these societies took - with local property held by a succession of trustees-judges found themselves with no other way to conceptualize these legal creatures except as corporations. ${ }^{22}$

I7 Ibid., 6I 8 .

I8 I8I3 N.Y. Laws 2 I9.

I9 Ransom Hebbard Tyler, American Ecclesiastical Law: The Law of Religious Societies, Church Government and Creeds (Albany: William Gould, I866), 59-60; Gable, Io Paige Ch. at 642-43.

$20 \quad$ I 785 N.J. Laws 255-58; I786-87 Del. Laws Io-I4; I790 Pa. Laws 40-43; I796 N.C. Laws 93 ; I802 Md. Laws ch. CXI; I805 Ga. Laws I5-I6; I8I I Mass. 387-89; I8I3 Ky. Laws 2II-I2; I8I7 Tenn. Laws 82 ; I8 I6 Oh. Laws 72-74; I8I9 Ala. Laws Iоo-OI; Me. Rev. Stat. 47I-74 (I82I); I824 Ind. Laws 265-67; I834 Ill. Laws I47-49; Ark. Rev. Stat. ch. I25 (I837); I838 Miss. Laws 57-58; Mich. Rev. Stat. tit. Iо ch. I (I838); I83839 Wis. Laws I36. Rhode Island, Louisiana, and Missouri appear not to have adopted general incorporation legislation but nevertheless granted charters to all religious societies which sought them. See David Benedict, $A$ General History of the Baptist Denomination in America (Boston: Lincoln and Edmands, I8I3), I:449-50; A General Digest of the Acts of the Legislature of Louisiana (New Orleans: B. Levi, I828), I:I49. On the exceptional case of Virginia, see Thomas Buckley, Establishing Religious Freedom: Jefferson's Statute in Virginia (Charlottesville: University of Virginia Press, 2013).

2 I S.C. Const. of I778, art. XXXVIII; McGarvie, One Nation under Law, I4I-2.

22 Executors of Joseph Burr v. Richard Smith, 7 Vt. 24I (I835). See also Weston v. Hunt, 2 Mass. 500 (I807); Christian Society in Plymouth v. Macomber, 46 Mass. I 55 (I842). 
Thus, while disestablishment certainly involved the abolition of privileges such as compulsory tithe assessments, a significant feature of disestablishment in many states was not the abolition of a privilege-incorporation-but rather its expansion to many more candidates. In his classic work on law and religion in American history, Mark deWolfe Howe devoted a chapter to the New York act (and unincorporated church litigation in New England), referring to this period as "the age of congregationalism." Howe noted that despite the protestations of the legislature that it would not "alter or change the religious constitutions or government" of the incorporating churches "in the least," the act functionally transformed all denominations into congregational polities. Presbyterians might have their synods, Catholics their archbishops, but these institutions were essentially powerless as every church controlled its own property at the local, congregational level. ${ }^{23}$ Howe speculated that this refusal to give real force to churches' own forms of government was motivated by a desire "to require or favor democracy in ecclesiastical polity." ${ }^{24}$ A more likely influence may have been the ideology of republicanism to which more recent scholars have given significantly more attention than Howe.

For many republican theorists, the mark of destabilizing corruption that could undermine a republic was a concentration of property and privilege that could insulate an elite class from the will of the sovereign people. To the republican imagination, the monstrous end of this corrupt concentration of privilege was the imperium in imperio-a dominion within the dominion, a state within the state. ${ }^{25}$ Eighteenth-century theorists such as William Blackstone surmised that any entity exercising the marks of sovereignty "which constitutionally belonged to the king alone" essentially became a rival state, and for Blackstone, the clearest example of such an imperium in imperio was the "see of Rome" which tempted the English people into "paying ... obedience to papal process." 26

Enlarging on Blackstone's fears, many American commentators saw all religious groups-not just Roman Catholics - as chief rivals to republican sovereignty. In the New England disestablishment debates, the New Hampshire Patriot warned readers of the danger of "a law-religion" to the republican order, and the state's governor William Plumer argued that all churches tended to use their authority "to traduce and vilify the [state] government, to counteract and enfeeble its measures." ${ }^{27}$ In New York, the legislature rejected a popular proposal to appoint state chaplains, insisting that the final end of such measures would be "to establish ecclesiastical dominion on the ruins of our free republican institutions." ${ }^{28}$ To many jurists, religious groups-while accorded newly wrought freedoms under the constitution-had to be strictly supervised by the states, lest by their rival power and influence they might plunge the state into the type of corruption so feared by republican theorists.

23 In what became known as the trustee controversy, Roman Catholics in particular protested against the congregational structures of the New York law but ultimately submitted to its terms. See Patrick Carey, "The Laity's Understanding of the Trustee System, I785-I 855," Catholic Historical Review 64, no. 3 (I978): 357-76, at $37 \mathrm{I}-72$.

24 Mark deWolfe Howe, The Garden and the Wilderness: Religion and Government in American Constitutional History (Chicago: University of Chicago Press, 1965), 44-7.

25 Gordon Wood, The Creation of the American Republic: $1776-1787$ (Chapel Hill: University of North Carolina Press, 1998), 373, 58I; Daniel J. Hulsebosch, "Imperia in Imperio: The Multiple Constitutions of Empire in New York, I750-I777," Law and History Review I6, no. 2 (1998): 319-79.

26 William Blackstone, Commentaries on the Laws of England (1776), vol. 4, chap. 8, p. I I 5.

27 Quoted in William McLoughlin, New England Dissent, I630-1883: The Baptists and the Separation of Church and State (Cambridge, MA: Harvard University Press, I971), 2:882-8.

28 "Report of the Select Committee," no. 293 in Documents of the Assembly (New York: E. Croswell, I 832), 4:I2. 
Allison LaCroix has written that "[t]he specter of imperium in imperio would haunt colonial, and later national, political debate at least until ${ }_{7789 . "}{ }^{29}$ Into the early republic, LaCroix argues that Americans became more comfortable with the idea of divided sovereignty, refusing to see it as the "absurdity" previous theorists had insisted it was. ${ }^{\circ}$ Divided sovereignty may have become a more acceptable idea, but American lawmakers remained on the lookout for potential rival states and stamped them out with the battle cry of imperium in imperio. Across the Jacksonian era, from Indian Removal to the veto of the Second National Bank, from anti-Catholic nativism to the nullification crisis, imperium in imperio continually underpinned the legal basis for restricting or removing threats to the American legal order. ${ }^{3}$

The fear of an imperium in imperio thus helps to make sense of American church corporation law. While according greater religious freedom to a state's religious societies, it nevertheless prevented the concentration of land, power, and allegiance in a single corporation. Churches were incorporated only at the local congregational level, and the general incorporation acts severely restricted how much land or revenue a church corporation could command. Although a few states periodically raised these amounts to keep up with inflation and commercial expansion, property allowances remained quite limited. Well into the Jacksonian era, many eastern states forbade church corporations from owning more than two acres of land. ${ }^{22}$ Disestablishment by incorporation was thus designed to root out privilege-but also to keep it from growing back. In a recent article, Sarah Barringer Gordon has explored how these statutes limited and controlled the ways that churches accumulated and deployed wealth. 33 This article examines a different problem generated by the use of general incorporation statutes in the service of republicanism: the problem of the charter.

A central feature of general incorporation was the creation of hundreds of essentially charterless corporations that could nevertheless hold and deploy property. All that was statutorily required for registering a religious corporation was a list identifying the names of the trustees and specifying the manner of their election. ${ }^{34}$ Significantly, nothing in the process required churches to state even in a general way their corporate purpose or to specify a theological or ecclesiastical identity; and of course, unincorporated churches treated as corporations in state courts had no charters at all. Soon enough, churches that had undergone theological change, real or apparent, ended up in court, as factions claiming orthodoxy litigated their rights to control the doctrine and the temporalities of their assembly. How courts were to settle these disputes without reference to a founding charter-and without involving the state in picking a favorite theology-created the central puzzle that antebellum judges struggled to resolve.

\section{THE PROBLEM OF THE CORPORATE CHARTER}

In early republican corporate litigation, courts typically examined a charter to determine whether a challenged action was in keeping with the rights and duties delineated there. Charters thus

29 Alison LaCroix, The Ideological Origins of American Federalism (Cambridge, MA: Harvard University Press, 20I0), 8I.

30 Ibid., 25 n 5 I.

3 I See Forrest McDonald, States' Rights and the Union: Imperium in Imperio (Lawrence: University of Kansas Press, 2000); LaCroix, The Ideological Origins.

32 Sarah Barringer Gordon, "The First Disestablishment: Limits on Church Power and Property before the Civil War," University of Pennsylvania Law Review I62, no. 2 (2014): 307-72.

33 See ibid.

$34 \quad$ I784 N.Y. Laws 6I4; see also I8I3 N.Y. Laws 2 I 8. 
functioned like micro-constitutions, and for enterprise corporations, charters might be quite detailed. Early railroad charters, for instance, specified the path the rails would take and prohibited construction from deviating more than a hundred yards from the specified line. ${ }^{35}$ In most cases, judges and juries had an elaborate text specifying the purposes and means of running an enterprise, and judgments could be based upon one or another clause in these texts. ${ }^{36}$ By the late 1820 , states like New York had numerous statutory provisions empowering courts to remove trustees and directors for violating their duties or for exceeding the powers granted in their corporate charter. Actions that were ultra vires - "beyond the powers" enumerated in the charter-were legally void. 37

A number of states also followed New York in pointedly exempting religious corporations from these statutes. ${ }^{8}{ }^{8}$ Unlike the detailed charters worked out by legislatures for every other American corporation, church charters in a general incorporation scheme were sparse: Essentially, they stated only the name of the church, the number of trustees, and the annual date of their election. An ultra vires charge against such corporations therefore made little sense. Surely these corporations could do much more than merely elect trustees, but what defined the extent of their powers, and when could a court know that a church corporation had operated beyond its powers?

The Supreme Court's famous Dartmouth College case suggested a set of answers. Like much antebellum church litigation, the case arose from the shifting theological tides coursing through revivalist America. When the president of Dartmouth College, the revivalist Presbyterian John Wheelock, was removed by more traditional Calvinist trustees, a sympathetic Republican legislature attempted to amend the school's charter to change the composition of the board of trustees and allow more "perfect freedom of religious opinion." 39 Thus in this case, the corporation was not exceeding its proscribed powers; rather the state of New Hampshire was attempting to redefine what those powers were. The Court accordingly faced the question of what powers states had over chartered religious corporations.

Chief Justice John Marshall answered that, first of all, courts had to treat chartered religious organizations as private corporations. Where many scholars quickly jump to the assessment that the Court "privatized" churches and rendered them similar to businesses, neither Marshall nor counsel drew any commercial analogies. Rather, as Hendrik Hartog writes in his study of municipal corporate law, Marshall's main concern was to encourage the jurisprudential trend "to distinguish property from governance." 40

The Court was not concerned that religious societies should look like businesses, but that they already looked too much like states, performing public services and exercising governmental functions. If, as Marshall reasoned, religious institutions exercised governance, they were necessarily an extension of the state government, and any of their concerns or actions were ones "in which the legislature of the state may act according to its own judgment, unrestrained by any limitation of

35 First Baptist Church v. Utica \& S. R. Co., 6 Barb. 3 I 8 (N.Y. App. Div. I848).

36 See Thompson v. New York \& H. R. Co., 3 Sand. Ch. 625 (N.Y. Ch. I846). See also, for instance, Morton J. Horwitz, "Santa Clara Revisited: The Development of Corporate Theory," West Virginia Law Review 88, no. 2 (1985): 175-224; David Millon, “Theories of the Corporation," Duke Law Journal, no. 2 (I990): 20I62, 209; Lawrence M. Friedman, A History of American Law, 2nd ed. (New York: Simon \& Schuster, I985), 5I8-I9. ("Once, nothing was so central to the legal nature of corporations at the doctrine of ultra vires.").

37 Revised Statutes of the State of New York (1 829), 2:466.

38 Joseph K. Angell and Samuel Ames, A Treatise on the Law of Private Corporations Aggregate (New York: Hilliard, Gray, Little \& Wilkins, I832), 410-3.

39 Dartmouth College v. Woodward, I7 U.S. (4 Wheat.) 5 I8 (I8I9). On the history of the litigation, see McGarvie, One Nation under Law, I65-73.

40 Hartog, Public Property and Private Power, 192. 
its power." The unstated assumption was that anything less than plenary legislative authority over a unit of government would create the monstrous imperium in imperio..$^{\mathrm{I}}$ Plenary state power over religious societies, however, ran against the commitments of disestablishment, which in this case the Court was eager to uphold. ${ }^{42}$ Marshall therefore tread cautiously, carefully explaining why the Court was overriding a democratically supported state statute and noting that the case would have far-reaching implications for all American churches. "Almost all ... corporations ... which are created for the promotion of religion, of charity, or of education, are of the same character. The law of this case is the law of all," he noted.43

Marshall's solution was to declare that what religious societies like Dartmouth College did was not governance-it was merely the use and distribution of property, and these two activities were entirely separate legal categories. The position was not an easy one for the Court to maintain. Marshall spent many pages of his opinion arguing against New Hampshire's counsel that even though Dartmouth received public monies to house, feed, discipline, and prepare its students for civic life, it was not thereby transformed into a public institution and agent of the state. Such reasoning propelled Marshall to the position that a corporation's public status could only be defined by its charter, not by its activities, the source of its funds, or the beneficiaries for whom it acted. Since Dartmouth's charter did not declare it to be an instrumentality of New Hampshire, it could not be a public corporation. 44

What did Dartmouth's charter do? It showed that the school had been "incorporated for the preservation of its property." 45 The college possessed a rather elaborate charter drawn up decades before general incorporation, so the case did not present the Court with the type of problem that would confront state jurisdictions that had disestablished through general incorporation. Nevertheless, Marshall provided guidance in how such cases might proceed. Religious societies acquired their private property from donations "by individuals on the faith of the charter." Dartmouth's corporate duty was to adhere both to its charter and to the intent of the donors who had relied upon it. Cutting off the argument that Dartmouth owed any duty to its students or faculty (who approved of the Republican changes) Marshall asserted that these beneficiaries were not the proper representatives of the original donors, who were instead "represented by the corporation [which] is the assignee of their rights, stands in their place, and distributes their bounty, as they would themselves have distributed it, had they been immortal." ${ }^{6} 6$ Thus Marshall arrived at Dartmouth's defining feature: It did not govern; it distributed property, as any private individual might distribute property without becoming a state official. Religious societies were not arms of the government, to be controlled at the legislature's whim. Neither, in Marshall's logic, were they imperia in imperio because they were not imperia at all. They merely held property in trust. Attempting to heed the demands of disestablishment, the Court thus redefined the relationship of churches to the states. State legislatures could not reform or revoke chartered rights secured

4 I Dartmouth College, I7 U.S. (4 Wheat.) at 630.

42 Many have noted that Dartmouth College formed a turning point in the Federalist acceptance of disestablishment. Fearing moral disorder, Federalists tended to oppose disestablishment, and Federalist New England famously remained a regional holdout in the era of disestablishment. Disestablishment became more attractive, however, in the light of the circumstances surrounding Dartmouth College, in which a Republican legislature was seeking to uproot Calvinist orthodoxy in what was perceived to be a Federalist institution. See McGarvie, One Nation under Law, I 82-5.

43 Dartmouth College, I7 U.S. (4 Wheat.) at 645.

44 Ibid., 63I-44.

45 Ibid., 64I.

46 Ibid., 642 . 
by the constitutional laws of property. Courts could only follow traditional property law to ensure that property held in trust was not misappropriated or wasted. "The donors [or their representatives]," Marshall concluded, "if they can appear in Court at all, can appear only to complain of the trustees." 47

Accordingly, the earliest recorded church litigation in general incorporation jurisdictions looked to the law of trusts. The two key principles of charitable trust doctrine were elaborated by New York's chancellor Reuben Walworth in an 1832 case involving a contentious split in a Baptist congregation. On the one hand, the chancellor made clear that, "[o]ver the church, as such, the legal or temporal tribunals of this State do not profess to have any jurisdiction whatever .... All questions relating to the faith and practice of the church and its members belong to the church judicatories to which they have voluntarily subjected themselves." 48 Nevertheless, "[w] here the court is obliged to administer a trust, the chancellor cannot put his conscience into the keeping of any ecclesiastical or other tribunal," and must enforce the will of a donor to the society-including original donors, going back to those who financed the church at its inception. ${ }^{49}$ The tension between these two principles - allowing freedom of faith and conscience while enforcing the trust of (in many cases, long dead or anonymous) charitable donors-reflected a larger tension introduced by Dartmouth College. Churches no longer counted as sovereign governing bodies and therefore no longer raised the threat of imperium in imperio, but much of what churches did looked very much like sovereign governance and lawmaking, especially when they sought enforcement for their ecclesiastical rules in American courts. The freedom of religious actors in the present thus continually ran up against settled religious identities of the past.

\section{GABLE V. MILLER AND THE CONDITIONS OF RELIGIOUS FREEDOM}

Disestablishment-by-incorporation thus led to a paradoxical result. Just when disestablishment in the name of religious freedom became entrenched across America (New England disestablished gradually across the I 820 s and into I 833) and in Supreme Court doctrine, state courts ever more invasively scrutinized church doctrine and personal belief, the very area Chancellor Walworth and Chief Justice Marshall had proclaimed exempt from state interference. Perhaps no case illustrates this paradox better than Gable $v$. Miller, a controversy that grew out of the later fortunes of the German Reformed Church in New York City.

At the time the Reverend Kern was called to pastor the German Reformed Church, he impressed upon the consistory that "independency in churches was very dangerous both to the church and pastor." $5 \circ$ In order to safeguard against innovations in doctrine, and to provide a sure and steady

47 Ibid., 642-3.

48 First Baptist Church in Hartford v. Witherell, 3 Paige Ch. 296, 30 I (N.Y. Ch. I 832).

49 Ibid., 304. The law of charitable trusts, with its heavy reliance on the intent of a voluntary donor, helped judges to make sense of the new religious corporations, but it proved inappropriate and unnecessary for governing for-profit corporations, and New York chancery developed a different set of rules. Less than a year after the Baptist case, Chancellor Walworth held in a suit against an insurance corporation that directors would not be held liable for a loss of funds where no fraud or abuse of process had been involved. See Scott v. Depeyster, I Edw. Ch. 5 I 8 (N.Y. Ch. I 833). The case reads like an early instance of the modern business-judgment rule, under which courts refuse to examine the content of corporate decision making and restrict themselves to ensuring that corporate management follows proper procedures. See Dodge v. Ford Motor Co., 204 Mich. 459 (I9I9); see also Omnicare, Inc. v. NCS Healthcare, Inc., 8I 8 A.2d 9I4 (Del. 2003). Miller v. Gable, 2 Denio 492, 565 (N.Y. I 845 ). 
supply of able ministers, Kern recommended the congregation place itself under the authority of a broader association of churches. Union with German Lutherans was clearly out of the question, for the German Reformed church had been founded in 1758 precisely to escape the "deplorable condition" of having to attend Lutheran churches in order to worship in German. ${ }^{51}$ Kern instead placed the church under the ecclesiastical authority of the Dutch Reformed Classis of Amsterdam, which shared the same faith, if not the same language, and which had already founded numerous churches in New York. $5^{2}$

Over time the strength of the association between the German Reformed Church and the classis of Amsterdam (and then of New York after Independence) waxed and waned. Fellowship was disrupted by the Revolution and not restored until I799. Participation in the classis appears to have ceased entirely between 1805 and I $8 \mathrm{IO}$, only to be resumed with more or less regularity afterwards. ${ }^{53}$ Finally in 1822 , having amassed property holdings totaling near \$50,000 and a large membership that included John Jacob Astor, one of the richest Americans of his day, the German Reformed Church relocated to a new building on Forsythe Street and informally severed ties with the Dutch Reformed classis. ${ }^{54}$

Over the next fifteen years, competing factions developed within the membership. Some favored a reunion with the Dutch Reformed classis and a return to more traditional teaching and practice, while others celebrated the congregation's independence and greater liberality. Among the half dozen ministers called to the church during these years, at least four had been ordained Lutherans. ${ }^{55}$ The church reached a crisis in 1837 , when the opposing factions maneuvered to take control. Of the church's nine trustees, five publicized their intention to return the church to the Dutch Reformed classis. The minority called for an election to reduce the number of trustees and effectively ousted three pro-classis opponents. (The displaced trustees later alleged the election was fraudulent.) The two factions then each called its own minister and sued each other in chancery. ${ }^{56}$ Services were suspended until $\mathrm{I} 838$, when a vice chancellor granted a preliminary motion for the pro-independence trustees - represented by the trustee Jacob Miller-allowing them possession and use of the church premises until the resolution of the case, a resolution that would not come for another seven years. In the meantime, those committed to Reformed theology and classis authority-represented by Henry Gable-withdrew to an unused chapel on I 7th Street with their minister, John Ebaugh, who suspended communion pending the outcome of the litigation. ${ }^{57}$

In all, lawyers for each faction argued the case three times between I 838 and I 845 . Gable's pro-classis trustees secured the services of David Graham Jr., one of the most effective-and well-compensated-solicitors in Manhattan. ${ }^{8}$ Relying on chancery's settled rule to enforce the intentions of voluntary contributors to charity, Graham argued that over the years, the many donors that had given to the church had two clear expectations about the type of ministry they

5 I Ibid., 50I.

52 Gable, Io Paige Ch. at 629-30.

53 Ibid., 64I-44.

54 Miller, 2 Denio at 499. Of course, since the German Reformed Church owned all of its own property, the Dutch classis had no material recourse whereby it could secure the loyalty of the congregation.

55 See ibid., 508.

56 Ibid., 492.

57 The history of the litigation is rehearsed in A Vindication and Defense of the German Reformed Church and Its Pastor (New York: Cornell University Library, I85I) (New-York Historical Society).

58 Graham was also one of the earliest university professors of New York legal practice and expert in chancery procedure. See David Graham, Jr., A Treatise on the Organization and Jurisdiction of the Courts of Law and Equity in the State of New York (New York: Halsted and Voorhies, I839). 
were supporting: a church attached to the Dutch Reformed ecclesiastical structure, and a church that maintained strict adherence to the Calvinist doctrines of salvation. The latter point became the heart of the case, and Graham focused especially on the fact that the pro-independence trustees had used their influence to call several Lutheran ministers to the church, yet "the German and Dutch Reformed churches were strictly Calvinistic in doctrine, and that the Lutheran was Arminian, and that the difference between these modes of belief was fundamental." 59

Attorneys for Miller responded that "the doctrines denominated Calvinistic and Arminian are somewhat variant, but not, as they think, irreconcilable or repugnant to each other," and that either way, a particular view of God's sovereignty or election in salvation was not fundamental to the church's identity, for "a sincere belief in the cardinal principles of the Christian religion and a pure and unspotted life, is sufficient to admit candidates into communion with the church." 60 The main attack, however, was against the charitable trust doctrine itself, and the trustees encouraged the court simply to endorse majority rule. Rather than tie themselves to the implied intentions of unknown donors, courts should instead, they argued, recognize "the right to introduce whatever doctrine, worship and church government a majority of the members shall think proper." ${ }^{1}$

At the case's first hearing, the assistant vice chancellor for New York City, William McCoun, unhesitatingly rejected the trustees' call for majority rule. In his view, despite disestablishment, "Christianity is recognized as part of the law of the land," yet under an unquestioning rule of majoritarianism, "any Christian church built on property given expressly for the spread of the gospel [could] be converted, at the will of the majority, into a hall for teachers of apostacy, blasphemy, or atheism," a conversion chancery should not countenance. ${ }^{62}$ As a first principle, then, "the will of the majority of the holders of the property is not to be regarded." 63

Having committed himself to enforcing the intentions of charitable donors, the vice chancellor had to determine just what kind of a ministry donors thought they were supporting over the years, and to that end, "[a] number of clergymen and other persons were examined respecting the characteristics of the Calvinistic and Arminian doctrines, and the tenets respectively held by the German Reformed, the Dutch Reformed and the Lutheran churches" - the total printed examination record came to around 250 pages. ${ }^{64}$ The Reverend Kern's cornerstone statement landed at the center of this inquiry, and ultimately the vice chancellor determined that the sitting trustees had not substantially departed from "the reformed doctrines of Heidelburgh and Switzerland." To arrive at this conclusion, the vice chancellor discussed at length the intricacies of Reformation theology, arguing that significant differences between the Heidelberg Catechism and the teaching of Ulrich Zwingli (standing in for Swiss reformed theology) meant that the true character of the German Reformed Church could not be certainly identified with doctrines that necessarily excluded Lutherans from the pulpit. ${ }^{65}$

59 Miller, 2 Denio at 509.

60 Ibid., 497.

6I Of course under this standard the trustees' lawyers argued that the court should have found for the trustees, for the Lutheran ministers called by the trustees had "preached the doctrines and inculcated the faith of the German Reformed Church, as accepted, practiced and believed by the congregation of that church," or at least a majority of that church. Ibid., 498.

62 Ibid., 524 .

63 Ibid., 525 .

64 Ibid., 509; Trial of Impeachments: Miller v. Gable, 92-335.

65 To quote a sample of the vice chancellor's theological analysis: "Zuingle [sic] held, undoubtedly, that every thing took place according to the predestination of God. But he explicitly held that unbaptized infants were saved; that 
The vice chancellor's opinion, delivered in December I 842, was swiftly appealed by Graham to Chancellor Walworth. Handing down his own decision in the spring of 1844 , Walworth eagerly jumped in to the theological fray. He criticized the vice chancellor for relying too much on Zwingli's early writings, for it was clear that Zwingli's successor, Heinrich Bullinger, "was unquestionably a Calvinist." 66 The chancellor then surveyed the Belgic Confession, Helvetic Confession, French Confession and Articles of Lambeth to conclude that reformed doctrine was in essential agreement on points totally inconsistent with the doctrines of Lutheranism, which "became semi-Pelagian soon after the death of Luther, if they were not so from the commencement of the Reformation." ${ }^{67}$ Holding for the ousted pro-classis membership, the chancellor concluded that "[t] hose who contributed to the funds of this society, therefore, whoever they were," dedicated them to upholding orthodoxy as defined by the Calvinist confessions. ${ }^{68}$

Walworth agreed wholeheartedly with the vice chancellor's rejection of any type of majoritarian rule that might allow doctrine to evolve with the changing makeup of the congregation. The court would not abdicate its duty to enforce a propertied trust, nor would it endanger the moral underpinnings of the republic. Equally remarkable was the historical precision with which the chancellor defined Calvinist orthodoxy, despite the imprecision with which he identified the donors who supposedly insisted on this orthodoxy. Never mind that in I8I 7 the king of Prussia had begun to unite the Lutheran and Reformed churches across the German territories, what defined reformed faith and practice were seventeenth-century confessions and catechisms. Yet the chancellor could only surmise at best that donors - "whoever they were"-actually intended these particular confessions to control their devise. ${ }^{69}$ In the absence of detailed and definite charters, courts turned to the law of charitable trusts, yet donor intent was proving to be just as murky a basis upon which to found legal decisions.

Both decisions in this case look strikingly different from what twenty-first-century jurists would expect "freedom of conscience" or the "separation of church and state" to look like. Recent scholarship on American disestablishment has stressed precisely this point. Several historians have ventured beyond the founding era to explore areas of local public law in which American courts and legislatures maintained a "Protestant moral establishment." 70 Steven Green, for instance, regards the founding era as an experiment in "political disestablishment," that left undisturbed a close connection between Protestant evangelicalism and legal regulation through most of the nineteenth century. ${ }^{7 \mathrm{I}}$ Thus by claiming that "Christianity is recognized as part of the law of the land," New York's vice chancellor was not consciously seeking to disrupt what disestablishment had supposedly already settled; rather, he was merely maintaining a long tradition in American law, echoing the sentiments and indeed the very words of greater legal luminaries such as James Kent, former chancellor of New York, and Joseph Story, a Supreme Court justice and professor at Harvard Law

the heathen were as much within the efficacy of atonement as others; and that the death of Christ was an expiation for the sins of the whole world, not confined to the elect to whom Christ is made known." Miller, 2 Denio at 529.

7 I See Green, The Second Disestablishment: Church and State in Nineteenth-Century America (Oxford: Oxford University Press, 2010). 
School. That disestablishment brought meaningful religious freedom has to be regarded, in the words of David Sehat, as a "myth." 72 And indeed, the massive coercion behind a case like Gable v. Miller seems to make the idea of the American state's non-interference in religion seem quite mythical.

However, if antebellum jurists appear to have so readily contradicted their praise of religious freedom with their rulings, perhaps it is the view from the twenty-first century that requires adjustment. Gable may reveal a lot more about religious freedom than that disestablishment had not, after all, progressed as far as many Americans once believed. It may in fact demonstrate that jurists had sound legal reasons for believing they were advancing the causes of disestablishment, religious freedom, republicanism, and a generalized Christianity simultaneously. Indeed, a striking feature of the 600-page record in Gable v. Miller is not how much it invokes concepts of charitable trust or religious freedom, but rather how much it reads like an analysis from another body of law known at the time as conflict of laws.

More often referenced today as "choice of law," conflict of laws received its first and finest systematic treatment in America at the hand of Justice Joseph Story in I 834.73 In a legal landscape marked by overlapping jurisdictions and plural sources of rules - from common law to custom, admiralty to equity, local level, state level, federal and even international levels - the field of conflicts served as a body of meta-rules that determined not the substance of a legal rule, such as whether a contract had been validly executed, but rather the appropriate decision maker and authoritative body of rules that should in turn decide a dispute sounding in contract. In essence, conflicts answered the questions "Who decides?" and "What law applies?" Frequently a conflicts analysis ended with the judge applying the law of the applicable jurisdiction himself rather than his transferring the case to that jurisdiction. That is, if choice-of-law rules directed that the law of Massachusetts-or federal law, or French law-applied, a New York judge did his best to figure out what that law was and applied it accordingly. 74

To return to the record in Gable, the chancery examiners seemed intent to scour Calvinist creeds in the same way judges customarily informed themselves of custom or foreign law when a conflictof-laws analysis so directed. That is, they treated Calvinism as a foreign legal system.

[Q:] From what, as the highest authority, are the doctrines of the Reformed Dutch Church derived? [A:] From the acts of the Synod of Dordrecht [Dort], convened in Holland in about I6I8 or I6I9 I think. [Q:] Were the doctrines of the Reformed Dutch Church alone established by the Synod of Dordrecht? [A:] I believe there were delegates in that Synod from all the reformed churches excepting the Lutheran. ... [Q:] Have the doctrines of religious faith as promulgated by the Synod of Dordrecht ever been recognized by the Reformed Dutch Church of North America, and if so, state the time, place and manner of their recognition. 75

Such queries were as standard and routine as if the examiner needed to know if Georgia had adopted a rule that trespassers had no right to recover for their injuries. $7^{6}$ Charitable trust doctrine

72 Sehat, Myth of American Religious Freedom; People v. Ruggles, 8 Johns. 290, 297-8 (N.Y. I 8I I); Joseph Story, "Christianity a Part of the Common Law," American Jurist and Law Magazine 9, no. I8 (I833): 346-8.

73 See Story, Commentaries on the Conflict of Laws (Boston: Hilliard, Gray, and Co., I 834).

74 Story, Conflict of Laws, I93-4; Pearsall v. Dwight, 2 Mass. 84 (I 806); De Sobry v. De Laistre, 2 H. \& J. I9I (Md. I 807 ).

75 Examination of Philip Milledoler, in Trial of Impeachments: Miller v. Gable, Ioo-I.

76 And as Story explained, foreign law had to be proved just as any other fact. That is, judges could not simply declare what foreign law was, counsel had to offer written proofs and witness testimony under examination. Story, Conflict of Laws, 523-32. 
thus functioned as a choice-of-law clause in a contract or charter: By donating to the German Reformed Church, one was selecting Calvinist "law" to govern.

The importance of understanding charitable trust doctrine as a conflict-of-laws analysis is twofold. First, we can see that state courts were following the logic of Dartmouth College to a point in which the fear of an imperium in imperio no longer guided church-state jurisprudence. Chief Justice Marshall had declared unequivocally that religious societies were not states-they did not govern and were not political agents but merely users of private property. But by removing churches from the conceptual category of sovereign states, Marshall freed state courts to treat churches as precisely that: sovereign states that could serve as sources of law. To be sure, fear of an imperium in imperio remained deeply ingrained in the law since the structuring legislation continued to confine corporate identity and wealth accumulation to the local level, but such cautionary logic did not control judicial decisions. Indeed, charitable trust doctrine in many ways restored power to hierarchical denominations that had lost it due to the congregationalist bent of the general incorporation statute. As Gable itself illustrates, charitable trust doctrine could enforce loyalty to a classis or synod, in effect giving the higher level of organization real power over the property of a local congregation.

Second, the courts' deployment of charitable trust doctrine as conflict-of-laws analysis presents a clearer view of law and the conditions of religious freedom in antebellum America. 77 If one assumes, as many present commentators have, that religious freedom consists of rights held by an individual to be asserted only against the state, one may indeed struggle to find religious freedom in these cases. Instead, begin with the notion that at bottom, religious freedom assumes that there can exist an alternative legal order to the legal order of one or another American state. ${ }^{78}$ Such reasoning seems to accord with the understanding of this earlier era, and what is remarkable about these cases is that state judges respected these alternative legal systems enough to actually enforce their rules in American courts. Religious freedom was not purely a negative freedom, a freedom to be left undisturbed in one's conscience. It was also a positive liberty, a liberty that certain institutions could act in the world of property and contract in meaningful ways. In this sense religious freedom was a corporate freedom, the right of an aggregate to see its institutional rules and actions validated in the state courts.

Of course this respect ran only to certain institutions and could involve a significant amount of coercion. Conflict of laws necessarily assumed a precondition of compatibility - for instance, that only "republican" forms of government sufficiently protected due process to make plural sources of law among republican states suitable enough that a genuine option could exist between them. (Tellingly, Story listed "Christianity and Commerce" as the necessary preconditions in his treatise. ${ }^{79}$ ) Scholars are not wrong to speak of the qualified progress of disestablishment in this era, and as Gable illustrates, an overarching Protestant moral establishment restrained judges from simply enforcing majoritarian rule. In seeking to treat Calvinism as a legal system, judges focused their attention on settled doctrines and fixed points of development, bracketing off contemporary evolutions just as these same judges had been trained to disregard custom that did not reach back "time

77 This analysis derives concepts from J. Willard Hurst's seminal Law and the Conditions of the Freedom in the Nineteenth-Century United States (Madison: University of Wisconsin Press, 1956), though Hurst himself was not particularly concerned with examining the history of religious freedom.

78 See Robert M. Cover, "The Supreme Court 1982 Term-Foreword: Nomos and Narrative," Harvard Law Review 97, no. 4 (1983): 4-68; Christopher Tomlins, Law, Labor, and Ideology in the Early American Republic (New York: Cambridge University Press, I993), 25-6. 
out of mind." $8 \circ$ Nevertheless, in allowing people, both living and dead, known and anonymous, to choose Calvinism as their "choice of law" and by upholding those commitments in court, judges had reason to think they were infusing religious freedom with powerful new meanings.

\section{THE DECLINE OF CHARITABLE TRUST AND THE RISE OF MAJORITY RULE}

Had Chancellor Walworth's Gable decision stood, all of the property of the German Reformed Church as well as its corporate charter and identity would have transferred to the Calvinist Reverend Ebaugh and the members supporting him. However, a final appeal was taken to the New York Court of Errors, which reversed the chancellor.

At the time, the Court of Errors was composed of both the New York Senate and the three justices of the state Supreme Court. Among the five opinions delivered in the case, only Senator Thomas Barlow was inclined to support a rule allowing a majority of members or trustees "to deviate from the doctrine which prevailed at the time of the [original] donation," so long as such donations were not conveyed "in terms" specifying the support of a particular doctrine, a condition he believed did not hold in this case. ${ }^{81}$ Although no other judge or senator agreed with Barlow's analysis, his suggestion is an interesting one. By setting aside the chancellor's qualms about churches departing from Protestant orthodoxy, Barlow identified a functional alternative: Courts could enforce the written instructions of donors, and thus these instructions would essentially act as a type of substantive charter that these churches otherwise lacked. Courts would then be spared the theological investigation of a church's fundamental doctrinal law so long as donors were sufficiently clear about the type of ministry they were supporting.

The rest of the court ignored Barlow's suggestion of majoritarian rule. Rather, the other senators and judges assumed, like the decisions below, that chancery had the duty to enforce the intentions of the charitable donors, majority sentiment notwithstanding. But most agreed that those intentions were too unclear in this case to prevent the German Reformed Church from leaving the Dutch Reformed classis or from calling Lutheran ministers. ${ }^{82}$

One should not make too much of the fact that Chancellor Walworth was ultimately overruled in this case. Besides Senator Barlow, the Court of Errors did not question the logic of Walworth's decision, only its application. The total record on appeal included over six hundred pages of Reformation theology, with citations to many significant Protestant reformers, confessions, catechisms, and church historians. The Court of Errors treated Calvinism as a source of law, just as Walworth did. The courts differed, though, on what the law of Calvinism required in this case. Moreover, Gable v. Miller, though a striking case, was by no means unique. From I 830 until the Civil War, nearly every divisive point of Protestant theology likewise came into court with a request to enforce a charitable trust, including sabbatarianism, ${ }^{83}$ trinitarianism, ${ }^{84}$ the inheritability of $\sin$, and the real presence of Christ in the Eucharist ${ }^{85}$ - and those are just other cases from

80 On the use of custom and immemoriality in judicial inquiry, see Kunal M. Parker, Common Law, History, and Democracy in America, 1790-1900: Legal Thought before Modernism (New York: Cambridge University Press, 20II).

8 I Miller, 2 Denio at 549 .

82 Ibid., 540-70. The final decision of the Court of Errors was I4-3 favoring reversal.

83 First Baptist Church in Hartford, 3 Paige Ch. at 296.

84 Kniskern v. Lutheran Churches, I Sand. Ch. 439, 5 Io (N.Y. Ch. I 844).

85 Lawyer v. Clipperly, 7 Paige Ch. 28I, 284 (N.Y. Ch. I838). 
New York. ${ }^{86}$ Unlike Gable, most of these decisions resulted in the transfer of church property and corporate identity to the minority members without appeal. It is only because Gable ended in a successful appeal, however, that such rich records of this world of litigation have survived. ${ }^{87}$

New York overhauled its court system in the late I 840 , and the new state supreme court began to move church corporation cases down a different path. The leading case became Robertson $v$. Bullions, a controversy that erupted shortly after the events of Gable, though the case would not be settled until I 854 due to New York's jurisdictional restructuring. Robertson concerned the Presbyterian Congregation of Cambridge, a church founded in $\mathrm{I}_{7} 85$ but not incorporated under the New York Act until I 826. ${ }^{88}$ The church called the defendant Alexander Bullions as its minister, but in 1838 the local synod deposed and excommunicated Bullions from the Presbyterian Church. It appears from the court records that the rift between Bullions and the synod was personal not doctrinal, as Bullions had publicly expressed his doubts about the competency of various members to serve as trustees of the synod. ${ }^{89}$ Nevertheless, after Bullions' excommunication, a majority of the Cambridge congregation and their trustees continued to support him as their minister, refusing to install the synod's rival candidate.

In I839, a minority of the congregation which supported full adherence to the authority of the synod sued for the church property. Applying the charitable trust doctrine, the vice chancellor decreed in their favor citing the now-familiar logic that "all power of interference in churches ... must be referred to the rights of property." Under the laws of propertied trusts, the case was an easy one. The Cambridge congregation had from its very founding been attached to the local Presbyterian synod, an authority structure that was inherent to Presbyterianism itself. For a local congregation to flout the authority of its synod in the matter of ministerial qualification was to cease fulfilling a core function to which donors over the years had contributed. Accordingly, the vice chancellor transferred ownership to the minority trustees. ${ }^{9 \circ}$

Bullions appealed, but the case did not reach the New York Supreme Court until I 850 . In a lengthy decision, Judge Augustus C. Hand reviewed the case law, noting with dismay how great a legal gulf had widened between church corporations and corporations for private enterprise. ${ }^{91}$ Over the years New York had steadily withdrawn judicial scrutiny of the latter, removing trustees and transferring property only in instances of clear fraud or abuse of corporate procedure. Yet in the one area where the state was clearly committed to freedom of conscience, the court of chancery

86 For other representative cases from New England, the Mid-Atlantic, and the South, see A Full Report of the Case of Stacy, Decow, and Joseph Hendrickson vs. Thomas L. Shotwell (Philadelphia: P.J. Gray, I834); Report of the Case of Earle vs. Wood (Boston: Little, Brown \& Co., I 855 ); Wilson v. The Presbyterian Church of John's Island, I9 S.C. Eq. (2 Rich. Eq.) I92 (I846). For a partial list of the many other cases of this type, see Charles Z. Lincoln, The Civil Law and the Church (Cincinnati: Abingdon Press, 1916).

87 Appeal to the Court of Errors required that the Court of Chancery compile the entire record of the case and publish it as a single volume. See Trial of Impeachments: Miller v. Gable. Further, as litigation tends to beget litigation, so in this case the pro-classis Reverend John Ebaugh had a falling out with the Dutch Reformed classis in later years over the unwillingness of the classis to reimburse Ebaugh for litigation and other expenses incurred during the I 840 s. A spate of further litigation and counter-recriminations in the press sheds further light on the condition of the German Reformed Church during the lengthy Gable suit. See A Vindication and Defense of the German Reformed Church; A True Report of the Last Trial of Rev. J. S. Ebaugh (New York: n.p., I852) (New-York Historical Society).

88 Robertson v. Bullions (Robertson II), I I N.Y. 243 (I 854 ).

89 Robertson v. Bullions (Robertson I), 9 Barb. 64, 76 (N.Y. Ch. I 850 ).

90 Ibid., 76-8.

9 I Ibid., $87-93$. 
had exercised extraordinary "visitorial" powers, exemplified most brilliantly in Gable v. Miller.92 Citing Senator Barlow's rule with approval, Judge Hand then adopted it to determine the case. Unless grants to the Presbyterian Church had specifically called for its close and continual allegiance to the local synod, trustees would be free to employ the property as they best saw fit, and the vice chancellor's decree was thus substantially overruled. 93

Robertson then appealed and the case finally reached the newly formed New York Court of Appeals in I854, where Judge Hand's majoritarian rule was upheld. ${ }^{94}$ According to Judge Samuel Selden, the notion of trusteeship had gradually diverged into two separate paths for religious corporations and ordinary civil corporations. In "other corporations" - that is, private enterprise corporations - trustees were "the managing officers and agents of the society, clothed with the aggregate powers of the corporators, representing their interests and entrusted with a discretionary charge of their temporal affairs." But in religious corporations, courts had treated trustees not as corporate directors but as trustees probating an estate, their discretion scrutinized at every turn by the courts of equity and bound to donative intent. This posture required "enumerable judicial enquiries into modes of faith, shades of religious opinion, and all those subtleties which attend the diversities of religious belief." 95

Judge Selden's solution was to find that church trustees were officers "in the same sense [as] with the president and directors of a bank, or of a railroad company." Ruling in favor of the majority trustees supporting Bullions, Selden adopted a rule that relied on members of the church to police its own doctrinal and ecclesiastical faithfulness through an election process. Trustees, Selden declared, were accountable not to donors of property but to their beneficiaries, the current church members. Over trustees "the body corporate retains control, through its power to supersede them at every recurring election." ${ }^{66}$ Thenceforth, courts were to restrict themselves to ruling only on the procedural fairness in the appointment and removal of trustees from office after duly authorized corporate elections.

Mark deWolfe Howe regarded Robinson a "surprising reversal of doctrine," and reasoned that over the decades "judges had discovered their own incompetence as theologians." Charitable trust doctrine "entangled [them] in the refined intricacies of theology and religious dogma," and judges finally revolted against being "compelled to master the esoteric learning of the churchmen and the obscure traditions of the churches." 97 But just about any nineteenth-century case involved judges in esoteric learning and obscure traditions: Every choice-of-law analysis required judges to become at least temporary experts in fields they had never before encountered.

Considering charitable trust doctrine through a conflict of law paradigm, Robinson indeed inaugurated a shift, but a much more subtle one than Howe and other scholars have surmised. The Robinson court confronted the fact that in most church litigation, some church tribunal-either a board of trustees or a synod or the congregational membership itself-had already undertaken to decide the case. Rather than treat church doctrine and tradition as a body of foreign law waiting to be applied de novo by American courts, the Robinson judges essentially treated these church tribunals as competent foreign courts. Just as New York would uphold the decision of a New Jersey court so long as basic due procedures had been applied, so now New York would allow the

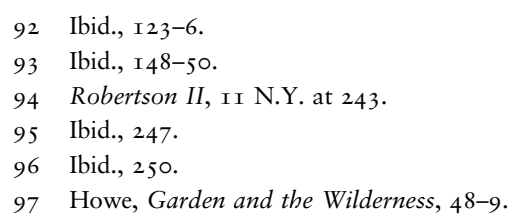


judgments of a church's decision makers to stand, even if the New York judges themselves might have reached a different substantive decision. $9^{8}$ Thus the logic of the charitable trust cases - that churches could be treated as semi-sovereign states-persisted, and even grew in influence through the move to majoritarian rule. Religious societies not only possessed an alternative legal order, states now allowed religious societies to police themselves. Henceforth, courts would inquire not into church doctrine but into procedure: Decisions made by duly elected trustees in a timely manner deserved deference.

Hand and Selden's language makes their decisions sound as though religious corporation law was now being made conformable to banking and railroad corporation law, yet a significant distinction remained between these two corporate forms. Although banks and railroads were governed by shareholder voting, they also held highly specific charters that constrained their power over property through a variety of mechanisms - all enforceable in court. 99 Thus although the tone of the decision indicated that a well-known model was being extended to religious corporations, Selden's rule created something different. Religious corporations in New York possessed charters that specified nothing more than the procedure of trustee elections, they registered these charters under a general incorporation statute without resorting to the legislature, and now members controlled the theological and ecclesiastical direction of the corporation, unconstrained by doctrines of public purpose, charitable trusts, or substantive rights and duties defined by a charter. New York's new administrable replacement for a substantively detailed charter involved trusting the churches with even greater powers of self-governance through "shareholder" voting, a model to which Selden's chosen examples of banks and railroads would not attain until the I870s or later. ${ }^{\text {Ioo }}$

\section{CONCLUSION: RELIGION, ENTERPRISE, AND LAW IN THE AGE OF DISESTABLISHMENT}

The republican fear that churches could be rival sovereign states structured the law of disestablishment: In most states across the early republic, all churches gained the once exclusive right to incorporate, but incorporation applied only to local congregations with strict limits on the amount of property they could hold. In its own handling of disestablishment, the Dartmouth College Court reasoned that churches did not exercise governance and thus implicitly should not be conceived of as rival sovereignties. Churches merely distributed property in trust, trusts that were controlled by the terms of corporate charters and the intent of church donors. Given the vagueness of church charters under general incorporation schemes and the uncertain intent of anonymous or deceased donors, state courts allowed trust law to function as a conflict of law analysis: Judges treated religious doctrine as a foreign legal system with rules that could be ascertained and accorded respect in American courts.

Paying attention to a remarkable set of litigation across the I 840 s, in which courts inquired into the details of theological doctrine in order to award the church property to a faithful minority, tells us much about the ways Americans could conceive of religious liberty as a positive institutional

98 Joseph Story described this body of law in "Foreign Judgments," in Commentaries on the Conflict of Laws.

99 Although New York began to extend general incorporation to other industries as early as I 8 I I, banks and railroads continued to be chartered through special enactments of the legislature well into the nineteenth century. For an example of a routine, yet detailed, bank incorporation, see I863 N.Y. Laws $290-5$.

Io० See Robert E. Wright, "Capitalism and the Rise of the Corporation Nation," in Capitalism Takes Command: The Social Transformation of Nineteenth-Century America, ed. Michael Zakim and Gary J. Kornblith (Chicago: University of Chicago Press, 20I2), I45-68. 
right rather than a merely negative individual freedom. To trace these developments, however, historians of American law and religion must look beyond First Amendment categories of free exercise and establishment and consider the everyday law of trusts, property, and incorporation through which religious actors had to navigate. ${ }^{\text {Ior }}$

This story also illustrates why we should be wary of claims that disestablishment rendered churches like private businesses in the open market. Mark deWolfe Howe rightly noted that New York's religious societies act was "a general incorporation act" - that is, it set up a registration system whereby any religious society could incorporate without a legislative act conferring the special privilege of a corporate charter. ${ }^{102}$ Nevertheless, many scholars and casebooks have missed Howe's lesson and continue to repeat the mythology that New York initiated general incorporation with its law of manufactures in I 8 I I. ${ }^{103}$ Though these works rightly recognize New York as the pioneering jurisdiction, they miss the innovative domain: churches secured a system of general incorporation thirty years before manufacturers did.

Although courts became more deferential to the business judgment of corporate directors across the nineteenth century, most of the significantly capitalized corporations such as banks and railroads remained confined by powers and duties laid out in elaborate charters. Once again, American churches were decades ahead of private enterprise in securing both open-ended charters with judicial deference to internal corporate decision making.

Business historians such as Gregory Mark have identified a third salient development in American enterprise corporations: Lawmakers over the course of the century increasingly saw corporations less as servants to specifically defined public goods (say passage over a waterway) and more as general opportunities for individual entrepreneurialism. In seeking to explain why and when these changes took place, however, scholars such as Mark have appealed to generalities such as a "spirit of egalitarianism" that pervaded Jacksonian America. ${ }^{104}$ Focus on the development of church corporations reveals the specific conceptual mechanisms by which Americans thought their way towards the possibility that a multitude of corporations could serve the public good by their very existence, without additional duties imposed by a charter. As one New Hampshire judge reasoned, all varieties of church corporations were "equally good for the purposes of civil society because they all inculcate the principles of benevolence, philanthropy, and the moral virtues." го Thus in securing general incorporation, judicial deference, and public acceptance, church corporations were years ahead of the business corporations with which they have often been compared. As economic historians increasingly turn their attention to issues of corporate governance and shareholder power, they too may learn much about the American approach to corporate power by focusing on religious societies. ${ }^{106}$

IOI A recent work pursuing this method is John W. Compton, The Evangelical Origins of the Living Constitution (Cambridge, MA: Harvard University Press, 2014).

IO2 Howe, Garden and the Wilderness, 45.

I03 Linda O. Smiddy and Lawrence A. Cunningham, Corporations and Other Business Organizations: Cases, Materials, Problems, 7th ed. (2010), 228-3 I; Liam Séamus O’Melinn, "Neither Contract nor Concession: The Public Personality of the Corporation," George Washington Law Review 74, no. 2 (2006): 20I-59, at 2I 8 n73.

I04 Gregory A. Mark, "The Personification of the Business Corporation in American Law," University of Chicago Law Review 54, no. 4 (I987): I44 I-83, at I453-4.

I05 Muzzy v. Wilkins, I Smith I, I3-I4 (N.H. I 803 ).

I06 For the turn towards issues of shareholder governance, see John Majewski, "Toward a Social History of the Corporation: Shareholding in Pennsylvania, I800-1840," in The Economy of Early America: Historical Perspectives and New Directions, ed. Cathy Matson (State College: Penn State University Press, 2006), 294- 
Ultimately this is a story of the possibilities and limits of the American legal tradition. Scholars over the last few decades have often referred to law as a "semi-autonomous" social field. For all the paradox inherent in the term, it nevertheless seems an apt description. The law of disestablishment was significantly structured by political ideologies that sought to stamp out rival sovereignties from forming or growing in America's churches, but these ideologies never quite penetrated deeply enough to alter long-established doctrines and judicial ways of reasoning about cases. As a New York judge wrote, "all power of interference in churches ... must be referred to the rights of property." ${ }_{107}$ Even if states refused to grant incorporation to all religious bodies, American judges had no other conceptual category for making sense of aggregations of individuals who wished to hold and deploy property as a perpetual, rights-bearing body. They thus allowed unincorporated churches into court and treated them as chartered corporations when they arrived. Before the Civil War-before the twentieth century, really-the novel terms of the First Amendment remained empty conceptual boxes of uncertain significance. But property, trust, and conflict-of-laws analysis were not empty categories. They were full of potential resources for judges to work their way towards blending or distinguishing church and state, charitable donor and propertied beneficiary, and theology and law.

\section{ACKNOWLEDGMENTS}

My thanks to Sarah Barringer Gordon, William Novak, Christopher Tomlins, Barbara Young Welke, and the participants of the New Worlds of Faith conference at the University of Pennsylvania Law School for their comments on an early draft. Thanks also to Jonathan Levy, John Matzko, Lincoln Mullen, the Religion of the Americas colloquium at Princeton University, and the Harvard-Princeton History Project for enthusiastic support and careful criticism of later drafts.

326; Colleen A. Dunlavy, "From Citizens to Plutocrats: Nineteenth-Century Shareholder Voting Rights and Theories of the Corporation," in Constructing Corporate America: History, Politics, Culture, ed. Kenneth Lipartito and David B. Sicilia (Oxford: Oxford University Press, 2004), 66-93.

I07 See above, note 89. For a foundational statement of law as semiautonomous, see Sally Falk Moore, "Law and Social Change: The Semi-Autonomous Social Field as an Appropriate Subject of Study," Law and Society Review 7, no. 4 (1973): 719-46. 